\title{
Protein C Activators from Snake Venoms and Their Diagnostic Use
}

\author{
P.M. Gempeler-Messina K. Volz B. Bühler C. Müller \\ Pentapharm Ltd., Basel, Switzerland
}

\section{Key Words}

Protein $\mathrm{C}$ activators . Snake venom enzymes · Diagnostic tools

\begin{abstract}
Proteinases converting the zymogen protein $C$ (PC) of vertebrates into activated PC have been detected in several snake venoms. Most PC activators have been purified from venom of snake species belonging to the genera of the Agkistrodon complex. Unlike the physiological, thrombin-catalyzed PC activation reaction which requires thrombomodulin as a cofactor, most snake venom activators directly convert the zymogen PC into the catalytically active form which can easily be determined by means of coagulation or chromogenic substrate techniques. Due to this feature, the fast-acting PC activator Protac ${ }^{\circledR}$ from Agkistrodon contortrix contortrix (southern copperhead snake) venom has
\end{abstract}

\begin{tabular}{ll}
\hline KARGER & @ 2002 S. Karger AG, Basel \\
Fax +41 61 306 12 34 & 0301-0147/01/0316-0266\$17.50/0 \\
$\begin{array}{l}\text { E-Mail karger@karger.ch } \\
\text { www.karger.com }\end{array}$ & $\begin{array}{l}\text { Accessible online at: } \\
\text { www.karger.com/journals/hae }\end{array}$
\end{tabular}

found a broad application in diagnostic practice for the determination of disorders in the PC pathway. Recently, screening assays for the PC pathway have been introduced, based on the observation that the PC pathway is probably the most important physiological barrier against thrombosis.

Copyright $\odot 2002$ S. Karger AG, Basel

\section{The Protein C Pathway}

The protein $\mathrm{C}$ (PC) pathway belongs to the most important anticoagulant mechanisms of blood coagulation.

In the blood coagulation cascade, formation of thrombin - a serine proteinase with pronounced procoagulant properties - occurs in the final phase.

The plasma concentration of the enzymatically inactive prothrombin is approximately 100 times higher than would be necessary for

Dr. Patrizia M. Gempeler-Messina

Pentapharm Ltd., Engelgasse 109, P.O. Box

CH-4002 Basel (Switzerland)

Tel. +416170648 48, Fax +41617064800

E-Mail patrizia.gempeler@pentapharm.com 
complete blood coagulation - after total conversion into active thrombin. The healthy organism has the particular property of inhibiting the clotting system with an efficient negative regulation. Thereby, lesions to blood vessels are repaired by the controlled, locally limited formation of a blood clot. Several mechanisms that inhibit the propagation of the clotting process on the endothelium surface have been described. The anticoagulant PC pathway, one of the anticoagulation mechanisms, regulates blood coagulation by inactivating factors VIIIa and Va, and increasing the fibrinolytic activity $[1,2]$. The mechanism can be described as follows: after binding of thrombin to thrombomodulin - a proteoglycan bound to the endothelium membrane PC is activated [3]. Activated PC (APC) together with its cofactor protein S (PS) [4] inactivates factors VIIIa and Va by proteolytic degradation and therefore thrombin formation is reduced.

$\mathrm{PC}$ is a vitamin-K-dependent glycoprotein with a molecular weight of 62,000. In blood, it circulates as an inactive zymogen of a serine proteinase. PC is synthesized in the liver. Its half-life amounts to $8 \mathrm{~h}$ and its concentration in plasma is $4 \mu \mathrm{g} / \mathrm{ml}$.

PS is also a vitamin-K-dependent blood clotting factor with a molecular weight of 70,000. Unlike other vitamin-K-dependent blood clotting factors, PS is not a zymogen of a serine proteinase; it is synthesized in the liver, in endothelial cells and in megakaryocytes. Its half-life amounts to $42 \mathrm{~h}$ and it circulates in blood at a concentration of $25 \mu \mathrm{g} / \mathrm{ml}$. The cofactor activity of PS towards APC is regulated by the capacity of PS to bind to C4bbinding protein (C4bBP) [5]. C4bBP plays an important part in the complement system. The complex C4bBP PS has no APC cofactor activity. Approximately $60 \%$ of PS is bound to $\mathrm{C} 4 \mathrm{bBP}$.

Snake Venom Protein C Activators

\section{PC Disorders}

Two types of congenital heterozygous PC deficiencies can be distinguished: PC deficiency type I, where activity and antigen are equally reduced, and PC deficiency type II where clotting activity is lower than antigen concentration. In rare cases of homozygous PC deficiency, fulminant, fatal thromboembolism already occurs in the neonatal phase [6].

Acquired PC deficiency is relatively frequent, as PC belongs to the first factors that are reduced due to liver dysfunction. Disturbances of PC synthesis are mainly observed in case of hepatic diseases, vitamin K deficiency and coumarin therapy. Increased conversion of PC takes place above all in disseminated intravascular coagulation, postoperatively, in insulin-dependent diabetes mellitus and in renal failure.

Increased PC concentration may be due to drugs, e.g., ovulation inhibitors or anabolics. Increased PC levels are also found in pregnancy.

Concentrations between 65 and $150 \%$ correspond to the normal range. Concentrations between 20 and $70 \%$ imply an increased risk of thromboembolism.

\section{PS Disorders}

Three types of familiar, heterozygous PS deficiencies can be distinguished. In type I, total and free PS antigen level are reduced; in type II, PS activity is reduced, but the antigen level of free and total PS is normal; in type III, PS activity and free PS are reduced, but the total PS antigen remains normal [7, 8]. Homozygous PS deficiency is extremely rare.

Acquired PS deficiency is mainly observed in case of hepatic diseases, vitamin $\mathrm{K}$ deficiency, coumarin therapy, chronic inflamma-

Haemostasis 2001:31:266-272 
tory intestinal diseases, disseminated intravascular coagulation and nephrotic syndrome.

Concentrations between 60 and $160 \%$ correspond to the normal range, concentrations below $60 \%$ bring about an increased risk of thromboembolism.

\section{APC Resistance}

APC resistance is associated with the most common hereditary defect predisposing to venous thromboembolism [9]. More than 97\% of APC resistance cases are caused by a point mutation in the factor $\mathrm{V}$ gene, replacing Arg 506 by Gln in the resulting factor V protein, also referred to as factor V Leiden [10]. Heterozygotes for this mutation have a 5- to 10fold increased risk of venous thrombosis, while homozygotes are even 50-100 times more susceptible. Due to the high prevalence of factor $\mathrm{V}$ Leiden in the normal population [11], this factor should be the first parameter to be evaluated in any scheme assessing a hereditary risk.

\section{PC Activators}

The following snake venoms have been described to contain PC activators [12-17]: $A g$ kistrodon contortrix contortrix, Agkistrodon contortrix mokasen, Agkistrodon contortrix pictigaster, Agkistrodon piscivorus piscivorus, Agkistrodon piscivorus leucostoma, Agkistrodon bilineatus, Agkistrodon blomhoffii ussuriensis, Agkistrodon halys halys, Bothrops moojeni, Bothrops pradoi, Vipera lebetina, Daboia russelli, Cerastes cerastes, Trimeresurus mucrosquamatus.

First results on the isolation of thrombomodulin-independent and fast-activating PC activator from $A$. contortrix contortrix (south- ern copperhead snake), and related PC-activating properties of enzymes from venom of Agkistrodon subspecies and in venom of A. piscivorus (eastern cottonmouth snake), Agkistrodon bilineatus (tropical moccasin snake), B. moojeni, B. pradoi (Prado's pit viper), Vipera lebetina (desert adder) and $C e$ rastes cerastes (Egyptian sand viper) were presented in 1985 at the Symposium on Animal Venoms and Hemostasis in San Diego, Calif. [18].

The commercial preparation $\operatorname{Protac}^{\circledR}$ - the purified form of the fast-acting PC activator from A. contortrix contortrix - has considerably simplified the determination of PC [1921]. Protac converts the zymogen PC very quickly, independently of thrombomodulin, into a serine proteinase which exerts the enzymatic and anticoagulant effects of PC. In contrast to thrombin, the activation product of Protac is not influenced by the inhibitory effect of PC inhibitor. Consequently, timeconsuming adsorption steps to separate PC from its inhibitor for the determination of PC are no longer required. Protac also activates PC from cattle, sheep, goats, rabbits, horses and pigs.

\section{Properties and Mode of Action of PC Activators}

Protein $\mathrm{C}$ activators are mainly characterized from Agkistrodon snake venom. According to a comparative study, PC activators can be divided into two groups [16]:

\section{PC Activators from New World Species of} the Genus Agkistrodon

Protein C Activators from A. contortrix Venom. A. contortrix contortrix crude venom is composed of up to 80 different proteins [22, 23]. Characterizations made by different laboratories [24-28] revealed the following prop- 
erties for the PC activator from A. contortrix contortrix. The activator is a serine proteinase with a molecular weight of 36,000-40,000 D and shows an isoelectric point in the $\mathrm{pH}$ range of 7.5-9. PC is activated by limited proteolysis and splits off the substrate Tos-Gly-ProArg-pNA. The anticoagulant and amidolytic activity is inhibited by serine proteinase inhibitors such as NPGB, PMSF, DFP, H-DPhe-Pro-Arg-chloromethylketone and the active center acylating inhibitor for serine proteinases, 2-ethoxy-6.7-dimethoxy-4H-3.1benzoxazine-4-one [29]. The amino acid sequence of the $\mathrm{PC}$ activator from $A$. contortrix has been completely elucidated [30]. The protein is composed of 231 amino acids with a calculated molecular weight of 25,095 D. Similarly to mammalian serine proteinases, the PC activator has His-40, Asp-85 and Ser177 in the catalytic active center. The primary structure of the PC activator from A. contortrix contortrix shows many homologies to other snake venom enzyme proteinases such as batroxobin from Bothrops atrox, flavoxobin from Trimeresurus flavoviridis, gyroxin from Crotalus durissus terrificus, crotalase from $C$. adamanteus and cerastobin from Cerastes vipera.

Protein $C$ Activator from A. bilineatus. The PC activator from A. bilineatus [31] has also been characterized. This activator has been shown to have a molecular weight of 35,00038,000 D by SDS-PAGE under reducing and nonreducing conditions. Analysis of the amino acid sequence revealed a strong homology to $\mathrm{PC}$ activator from $A$. contortrix venom.

\section{Protein C Activators from Old World}

Species of the Genus Agkistrodon

Protein C Activator from A. blomhoffii. A PC activator with a molecular weight of 44,000 D has been determined by SDS-PAGE in A. blomhoffii ussuriensis (Ussuri mamushi) venom [15]. This PC activator was described to prolong the aPTT in human plasma, and after intravenous injection to rats the aPTT proved to be prolonged, plasminogen activity increased and FV procoagulant activity decreased.

Protein C Activator from Agkistrodon halys halys. A PC activator with a molecular weight of 36,000-40,000 D and an antithrombotic effect in rats [14, 32] has been isolated from $A$. halys halys (Asian pit viper) venom. The difference between PC activators from New and Old World snake venom consists in the fact that PC activators from Agkistrodon from the New World have a molecular weight of less than 40,000 D and a pH optimum of 7.0-8.5, and activate $\mathrm{PC}$ from rat plasma to a lesser extent than PC from human plasma. PC activators from Agkistrodon species from the Old World have molecular weights greater than 40,000 $\mathrm{D}$ and a pH optimum between 5.0 and 6.5 , and activate PC from rat plasma to a higher extent than PC from human plasma.

\section{PC Assays Using a PC Activator from Snake Venom}

The presently applied methods of PC determination are either functional or immunochemical. Functional assays are either clotting assays or based on determinations using chromogenic assays [19, 33, 34]. They have been largely simplified by the introduction of Protac. The chromogenic assay is performed as follows: PC in plasma is activated with Protac and APC splits off a chromogenic substrate. This test is very easy and specific, can easily be automated for clinical use and shows an extraordinary accuracy.

In the PC clotting assay, patient plasma is prediluted with PC-deficient plasma to exclude any disturbing factors. PC is activated with Protac and the inhibitory effect of APC is determined by aPTT. Prolongation of the 
clotting time is proportional to the activity of $\mathrm{PC}$ in patient plasma. This assay too can be automated.

\section{PS Assays Using a PC Activator from Snake Venom}

Basically three types of assays can be recognized [35-40]: (1) Immunological assays for total PS; (2) Immunological assays for free PS; (3) PS functional assays. The APC cofactor activity can be measured as the prolongation of a prothrombin-time-based clotting assay [41], in which diluted test plasma, PS-depleted plasma containing Protac-activated PC, bovine brain tissue thromboplastin and calcium ions are mixed. The clotting time prolongation is proportional to the PS content in patient plasma. Chromogenic methods and aPTT methods have also been described.

\section{Screening Assays for the PC Pathway}

Recently, screening assays for the PC pathway have been introduced which are based on the observation that the PC pathway is probably the most important physiological barrier against thrombosis. For this reason, identification of a dysfunctional PC pathway should be the first step in order to assess an individual thrombosis risk. Several groups have described similar functional assays which are based on the following principle [42]: a screening test, e.g. aPTT, is performed on the sample with or without previous or simultaneous activation of PC by Protac.

The two clotting times are required in order to compensate any changes of coagulation factors which influence the individual aPTT of a sample. A functional PC pathway leads to a massive prolongation of the clotting time in the sample with the activator and thus to a PC ratio (the ratio of the clotting times with and without Protac) above the cut-off value for normals. The PC ratio is slightly instrument dependent and can be normalized with the help of a calibration plasma.

Pathological results are found in almost all patients with factor V Leiden or with PC deficiency, whereas the detection of PS dysfunction is less efficient. Other factors which influence the assay are lupus anticoagulants, the prothrombin mutation 20210 G/A or elevated factor VIII.

\section{APC Resistance Assay}

The following example of APC resistance assay (APC-R assay) was performed with the PC activator from $A$. contortrix contortrix [unpubl. data].

Sample plasma is prediluted with factorVV-deficient plasma and incubated at $37{ }^{\circ} \mathrm{C}$ with a specific factor $\mathrm{V}$ activator from Daboia russelli and phospholipids in the presence and absence of Protac. Coagulation is triggered by the addition of a factor-V-dependent prothrombin activator from Notechis scutatus in the absence of calcium. The time until clot formation is recorded. The ratio of clotting time with/without added Protac is calculated. Homozygous factor $\mathrm{V}$ Leiden gives a ratio below 1.0, heterozygous factor $\mathrm{V}$, a ratio between 1.0 and 2.0, and wild-type, a ratio above 2.0.

\section{Conclusions}

The active component Protac is a protease which causes the activation of $\mathrm{PC}$ and is used for the determination of PC, PS, APC-R and in global assays for determination of PC pathway disorders. Properties of PC activators 
from snake venom have been determined in a relatively short time and the PC activator from $A$. contortrix contortrix is now widely used as a diagnostic tool in medical research and clinical use.

\section{Acknowledgements}

We thank Ms. A. Galmiche for assistance in preparing the manuscript.

\section{References}

1 Esmon CT: The protein C anticoagulant pathway. Arterioscler Thromb 1992;12:135-145.

2 Dahlbäck B: The protein C anticoagulant system: Inherited defects as basis for venous thrombosis. Thromb Res 1995;77:1-43.

3 Esmon CT, Owen WG: Identification of an endothelial cell cofactor for thrombin-catalyzed activation of protein C. Proc Natl Acad Sci USA 1981;78:2249-2252.

4 Walker FJ: Regulation of activated protein $\mathrm{C}$ by a new protein. A possible function of bovine protein S. J Biol Chem 1980;255:5521-5524.

5 Dahlbäck B: Inhibition of protein $\mathrm{Ca}$ cofactor function of human and bovine protein $\mathrm{S}$ by $\mathrm{C} 4 \mathrm{~b}$-binding protein. J Biol Chem 1986;261: 12022-12027.

6 Reitsma PH, Bernardi F, Doig, RG, Gandrille S, Greengard JS, Ireland $\mathrm{H}$, Krawczak M, Ling B, Long GL, et al: Protein $\mathrm{C}$ deficiency: A database of mutations, 1995 update. On behalf of the subcommittee on plasma coagulation inhibitors of the scientific and standardization committee of the ISTH. Thromb Haemost 1995;73:876-889.

7 Gandrille S, Borgel D, Sala N, Espinosa-Parrilla Y, Simmonds R, Rezende $\mathrm{S}$, Lind $\mathrm{B}$, Mannhalter $\mathrm{C}, \mathrm{Pa}-$ binger I, Reitsma PH, Formstone C, Cooper DN, Saito H, Suzuki K, Bernardi F, Aiach M: Protein S deficiency: A database of mutations summary of the first update. Thromb Haemost 2000;84:918.
8 Gandrille S, Borgel D, Ireland $\mathrm{H}$, Lane DA, Simmonds R, Reitsma $\mathrm{PH}$, Mannhalter C, Pabinger I, Saito H, Suzuki K, Formstone C, Cooper DN, Espinosa Y, Sala N, Bernardi, F, Aiach M: Protein S deficiency. A database of mutations. For the plasma coagulation inhibitors subcommittee of the scientific and standardization committee of the international society on thrombosis and hemostasis. Thromb Haemost 1997; 77:1201-1214.

9 Dahlbäck B, Carlsson M, Svensson PJ: Familial thrombophilia due to a previously unrecognized mechanism characterized by poor anticoagulant response to activated protein $\mathrm{C}$ : Prediction of a cofactor to activated protein C. Proc Natl Acad Sci USA 1993;90:1004-1008.

10 Bertina RM, Koeleman BPC, Koster T, Rosendaal FR, Dirven RJ, de Ronde H, van der Veldon PA, Reitsma PH: Mutation in blood coagulation factor $\mathrm{V}$ associated with resistance to activated protein C. Nature 1994;369:64-66.

11 Rosen SB, Sturk A: Activated protein $\mathrm{C}$ resistance. A major risk factor for thrombosis. Eur J Clin Chem Clin Biochem 1997;35:501-516.

12 Stocker K, Fischer H, Meier J, Brogli M, Svendsen L: Protein C activators in snake venoms. Behring Inst Mitt 1986;79:7-47.

13 Meier J: Proteinases activating protein C; in Bailey GS (ed): The Enzymology of Snake Venoms. Fort Collins, Alaken, 1998, pp 253-285.

14 Bakker HM, Tans G, Yukelson LY, Janssen-Claessen TW, Bertina RM, Hemker HC, Rosing J: Protein C activation by an activator purified from the venom of Agkistrodon halys halys. Blood Coagul Fibrinolysis 1993;4:605-614.
15 Kogan AE, Bashkov GV, Bobruskin ID, Romanova EP, Makarov VA, Strukova SM: Protein C activator from the venom of Agkistrodon blomhoffi ussuriensis retards thrombus formation in the arterio-venous shunt in rats. Thromb Res 1993;70: 385-393.

16 Kogan AE, Makarov AN, Bobruskin ID, Strukova SM: Comparative study of protein $\mathrm{C}$ activators from the Agkistrodon snake venoms. Thromb Res 1991;2:75-80.

17 Sun L, Guang J, Huang S, Yu Q: Identification of protein $\mathrm{C}$ activator from nine species of Chinese snake venoms. Zhongguo Bingli Shengli Zazhi 2001;17:241-244.

18 Stocker KF, Meier J: Thrombin-like snake venom enzymes; in Pirkle $\mathrm{H}$, Markland FS (eds): Hemostasis and Animal Venoms. New York, Dekker, 1988, pp 67-84.

19 Martinoli JL, Stocker K: Fast functional protein $\mathrm{C}$ assay using Protac ${ }^{\circledR}$, a novel protein $\mathrm{C}$ activator. Thromb Res 1986;43:253-264.

20 Stocker K, Fischer H, Meier J, Brogli M, Svendsen L: Characterization of the protein $\mathrm{C}$ activator Protac ${ }^{\circledR}$ from the venom of the southern copperhead (Agkistrodon contortrix) snake. Toxicon 1987;25:239-252.

21 Stocker K, Fischer H, Meier J: Practical application of the protein $\mathrm{C}$ activator Protac ${ }^{\circledR}$ from Agkistrodon contortrix venom. Folia Haematol 1988;115:260-264.

22 Dyr JE, Suttnar J, Kornalik F: Assessment of a complex mixture of interacting proteins in the coagulant-active venom from Agkistrodon contortrix contortrix. Folia Haematol 1988;115:203-207. 
23 Suttnar J, Dyr JE, Kornalik F: Evaluation of individual variability in the composition of Agkistrodon contortrix contortrix venom by means of HPLC and two-dimensional PAGE. Folia Haematol 1988;115: 197-202.

24 Klein JD; Walker FJ: Purification of a protein $\mathrm{C}$ activator from the venom of the southern copperhead snake (Agkistrodon contortrix contortrix). Biochemistry 1986;25: 4175-4179.

25 Kisiel W, Kondo S, Smith KJ, McMullen BA, Smith LF: Characterization of a protein $\mathrm{C}$ activator from Agkistrodon contortrix contortrix venom. J Biol Chem 1987;262: 12607-12613.

26 Kisiel W, Choi E, Kondo S: Isolation of a protein $\mathrm{C}$ activator from southern copperhead venom. Biochem Biophys Res Commun 1987; 143:917-922.

27 Exner T, Vaasjoki R: Characterization and some properties of the protein C activator from Agkistrodon contortrix contortrix venom. Thromb Haemost 1988;59:40-44.

28 Orthner CL, Bhattacharya P, Strickland DK: Characterization of a protein $\mathrm{C}$ activator from the venom of Agkistrodon contortrix contortrix. Biochemistry 1988;27:2558-2564.
29 Stuerzebecher J, Neumann U, Meier, J: Inhibition of the protein C activator Protac ${ }^{\circledR}$, a serine proteinase from the venom of the southern copperhead snake Agkistrodon contortrix contortrix. Toxicon 1991;29: 151-155.

30 McMullen BA, Fujikawa K, Kisiel $\mathrm{W}$ : Primary structure of a protein $\mathrm{C}$ activator from Agkistrodon contortrix contortrix venom. Biochemistry 1989;28:674-679.

31 Nakagaki T, Kazim AL, Kisiel W: Isolation and characterization of a protein $\mathrm{C}$ activator from tropical moccasin venom. Thromb Res 1990;58:593-602.

32 Strukova SM, Kogan AE, Tara AA, Aaviksaar A: Antithrombotic effect of protein $\mathrm{C}$ activator from snake venom. Vopr Med Khim 1989;35: 115-119.

33 Marlar RA, Adcock DM: Clinical evaluation of protein C: A comparative review of antigenic and functional assays. Progr Pathol 1989;20: 1040-1047.

34 Francis RB, Seyfert U: Rapid amidolytic assay of protein $\mathrm{C}$ in whole plasma using an activator from the venom of Agkistrodon contortrix. Am J Clin Pathol 1987;87:619-625.

35 Bertina RM, Van Wijngaarden A Reinalda-Poot J, Poort SR, Bom VJJ: Determination of plasma protein $\mathrm{S}$ - the protein cofactor of activated protein $\mathrm{C}$. Thromb Haemost 1985;53:268-272.
36 Woodhams BJ: The simultaneous measurement of total and free protein $\mathrm{S}$ by ELISA. Thromb Res 1988; 50:213-220.

37 Edson JR, Vogt JM, Huesman DA: Laboratory diagnosis of inherited protein $\mathrm{S}$ deficiency. Am J Clin Pathol 1990;94:176-186.

38 Suzuki K, Nishioka J: Plasma protein $\mathrm{S}$ activity measured using Pro$\operatorname{tac}^{\circledR}$, a snake venom derived activator of protein C. Thromb Res 1988; 49:241-251.

39 Wolf M, Boyer-Neumann C, Martinoli JL, Leroy-Matheron C, Amiral $\mathrm{J}$, Meyer D, Larrieu MJ: A new functional assay for human protein $\mathrm{S}$ activity using activated factor $\mathrm{V}$ as substrate. Thromb Haemost 1989; 62:1144-1145.

40 Kobayashi I, Amemiya N, Endo T, Okuyama K, Tamura K, Kume S: Functional activity of protein $\mathrm{S}$ determined with use of protein $\mathrm{C}$ activated by venom activator. Clin Chem 1989;35:1644-1648.

41 Preda L,Tripodi A, Valsecchi C, Lombardi A, Finotto E, Mannucci PM: A prothrombin time-based functional assay of protein $\mathrm{S}$. Thromb Res 1990:60:19-32.

42 Dati F, Hafner G, Erbes H, Prellwitz W, Kraus M, Niemann F, Noah M, Wagner C: ProC Global: The first functional screening assay for the complete protein $\mathrm{C}$ pathway. Clin Chem 1997;43:1719-1723. 